\title{
Kistik Fibrozis Hastalarında Akciğer Tutulumunun Manyetik Rezonans Görüntüleme ile Değerlendirilmesi
}

\author{
The Evaluation of Lung Involvement in Patients with Cystic Fibrosis \\ By Using Mediastinal Magnetic Resonance Imaging
}

\author{
Gökçen Dilşa TUĞCU ${ }^{1}$, Sanem ERYILMAZ POLAT ${ }^{1}$, Mina GARIBBZADEH HIZAL ${ }^{1}$, \\ Beste KARAKAYA ÖZSEZEN ${ }^{1}$, Altan GÜNEŞ ${ }^{4}$, Güzin CINEL ${ }^{1}$
}

${ }^{1}$ Ankara Şehir Hastanesi Çocuk Hastanesi, Çocuk Göğüs Hastalıkları Kliniği, Ankara, Türkiye

${ }^{4}$ Ankara Şehir Hastanesi Hastanesi, Radyoloji Kliniği, Ankara, Türkiye

\section{ÖZ}

Amaç: Kistik Fibrozis (KF) hastalığında pulmoner yapısal değişikliklerin erken dönemde noninvaziv olarak gösterilmesi ile tedaviye daha erken başlanarak ve mevcut tedavi gözden geçirilerek komplikasyonların önüne geçilebilir. Erken dönem pulmoner yapısal değişiklikleri, pulmoner alevlenme öncesi ve sonrası tedavi yanıtını göstermede bilgisayarlı toraks tomografisi (BT) ile beraber mediastinal manyetik rezonans görüntüleme (MRG) kullanılmaya başlanmıştır. Bu çalışmanın amacı, kliniğimizde KF ile takip edilen ve kliniği stabil hastalarda eş zamanlı olarak toraks BT ve MRG çekilen hastalardaki radyolojik bulguların birbirleri ile karşılaştıııması ve hastaların bazı klinik ve laboratuar bulguları ile korelasyon yapılarak; takiplerinde uygun yöntemle görüntüleme yapmaktır.

Gereç ve Yöntemler: Ağustos 2018 - Şubat 2019 tarihleri arasında, hastanemiz Çocuk Göğüs Hastalıkları Kliniği'nde KF tanısı ile takip edilmekte olan, klinik olarak stabil 14 hastanın aynı gün çekilen BT ve MRG'leri geriye dönük olarak Helbich ve Eichinger skorlama sistemine göre incelendi. Hastaların demografik verileri, klinik ve laboratuar bulguları kronik kolonizasyon durumu ve genetik mutasyonları kaydedildi.

Bulgular: KF tanısı ile takip edilmekte olan, pulmoner alevlenme şikayeti olmayan 14 hastanın aynı gün çekilen BT ve MRG'leri geriye dönük olarak değerlendirildi. BT ve MRG bulguları karşlaştırıldığında Helbich skorlama sistemine göre sadece mozaik atenüasyon paterninde BT ile daha iyi tanımlandığı gösterildi ( $p=0.003)$. Helbich skorlama sistemine göre BT için ortalama skor 6.6 (1-17), MRG için 4.7 (0-15)'di. Eichinger skorlamasına göre MRG için ortalama skor 3 (0-16)'dı.Hastaların klinik ve demografik bulguları karşılaştııılı̆̆ında Phe508del homozigot mutasyonu olup P.aeruginosa ile kronik kolonize olan hastaların BT ve MRG skorları diğer hastalara göre anlamlı olarak daha yüksekti $(p=0.002)$.

Sonuç: KF hastalarında pulmoner etkilenmeyi göstermek için mediastinal MRG toraks BT kadar güvenilir; radyasyon içermediği için de tercih edilebilir bir yöntemdir. Mozaik atenüasyon gibi erken dönem akciğer bulgularının değerlendirilmesinde ise BT ile beraber kullanılabilir. Yakın zamanda KF hastalarındaki akciğer bulgularını göstermede deneyimli personel ve yeni çekim teknikleri ile MRG altın standart haline gelebilir.

Anahtar Sözcükler: Kistik fibrozis, Bilgisayarlı tomografi, Manyetik rezonans görüntüleme, Pulmoner tutulum

\section{(10)}

TUĞCU GD

ERYILMAZ POLAT S

GARIBZADEH HIZAL M

KARAKAYA ÖZSEZEN

GÜNEŞ A

CINEL G
: 0000-0002-9804-1200 $0000-0003-2309-7952$ 0000-0002-6922-4948 0000-0002-0052-8361 $0000-0002-0365-1218$ 0000-0002-6209-196X
Çıkar Çatışması / Conflict of Interest: Tüm yazarlar adına, sorumlu yazar çıkar çatışması olmadığını belirtir.

Etik Kurul Onayı / Ethics Committee Approval: Bu çalışmada ulusal ve uluslararası etik kurallara uyulmuştur. Çalışmamız için Ankara Çocuk sağlığı ve Hastalıkları Hematoloji Onkoloji Eğitim Araştırma Hastanesi, Klinik Araştırmalar Etik Kurulu'ndan 16.04.2019 tarih ve 2019-090 karar numarası ile onay alınmıştır.

Yazarların katkısı / Contribution of the Authors: TUĞCU GD: Araștırma ve/veya makalenin hipotezini veya fikrini oluşturan, Sonuçlara ulaşmak için planlama/metodoloji belirleme, Araștırma/çalıșmanın sorumluluğunu üstlenmek, ilerlemenin seyrini denetlemek, Hasta takibinde sorumluluk almak, ilgili biyolojik malzemelerin toplanması, veri yönetimi ve raporlama, deneylerin yürütülmesi, Sonuçların mantıksal olarak Yorumlanması ve sonuçlandırılması, Çalışma için gerekli literatür taramasında sorumluluk almak, Çalşmanın bütününün veya önemli bölümlerinin yazımında sorumluluk almak. ERYILMAZ POLAT S: Sonuçlara ulașmak için planlama/metodoloji belirleme, Hasta takibinde sorumluluk almak, ilgili biyolojik malzemelerin toplanması, veri yönetimi ve raporlama, deneylerin yürütülmesi. HIZAL M: Sonuçlara ulașmak için planlama/metodoloji belirleme, Hasta takibinde sorumluluk almak, ilgili biyolojik malzemelerin toplanması, veri yönetimi ve raporlama, deneylerin yürütülmesi. KARAKAYA ÖZSEZEN B: Hasta takibinde sorumluluk ilgili biyolojik malzemelerin toplanmaSı, veri yönetimi ve raporlama, deneylerin yürutülmesi. KARAKAYA OZSEZEN B: Hasta takibinde sorumluluk
almak, ilgili biyolojik malzemelerin toplanması, veri yönetimi ve raporlama, deneylerin yürütülmesi. GÜNEŞ A: Araștırma ve/veya makalenin hipotezini veya fikrini oluşturan, Sonuçların mantıksal olarak Yorumlanması ve sonuçlandırılması, Çalıșma için gerekli literatür taramasında sorumluluk almak Yazım ve dilbilgisi dışında bilimsel olarak gönderilmeden önce makaleyi gözden geçirme.CiNEL G: Araștırma/çalışmanın sorumluluğunu üstlenmek, ilerlemenin seyrini denetlemek, Sonuçların mantıksal olarak Yorumlanması ve sonuçlandırılması, Çalışma için gerekli literatür taramasında sorumluluk almak, Yazım ve dilbilgisi dışında bilimsel olarak gönderilmeden önce makaleyi gözden geçirme.

Atıf yazım şekli / How to cite : Tuğcu GD, Eryılmaz Polat S, Garibzadeh Hızal M, Özsezen Karakaya B, Güneș A, Cinel G. Kistik Fibrozis Hastalarında Akciğer Tutulumunun Manyetik Rezonans Görüntüleme ile Değerlendirilmesi. Türkiye Çocuk Hast Derg 2022; 16: 53-59.

Ek bilgi / Additional information: Bu çalışma 2019 ylında Türk Toraks Derneği 22. Yıllık Kongresinde sözel bildiri olarak sunulmuştur.
Yazışma Adresi / Correspondence Address:

Gökçen Dilşa TUĞCU

Ankara Șehir Hastanesi Çocuk Hastanesi,

Çocuk Göğüs Hastalıkları Kliniği, Ankara, Türkiye

E-posta: gokcendtugcu@gmail.com
Geliş tarihi / Received : 06.01.2021 Kabul tarihi / Accepted : 15.02.2021 Elektronik yayın tarihi $\quad$ : 28.05.2021 Online published

DOI: 10.12956/tchd.854953 


\section{ABSTRACT}

Objective: In Cystic Fibrosis (CF) disease, complications can be avoided by noninvasively demonstrating pulmonary structural changes in the early period by starting treatment earlier and reviewing the current treatment. Computed thoracic tomography (CT) and mediastinal magnetic resonance imaging (MRI) have been used to show early pulmonary structural changes and treatment response before and after pulmonary exacerbation. The aim of this study is to compare the CT and MRI findings of CF patients with some clinical and laboratory findings, and to perform imaging with an appropriate method in their follow-up.

Material and Methods: CT and MRls of 14 clinically stable CF patients August 2018 and February 2019 were retrospectively analyzed according to the Helbich and Eichinger scoring system. Patient's laboratory findings, chronic colonization status and genetic mutations were recorded.

Results: According to Helbich scoring, the mean score in CT was 6.6 (score range 1-17), while MRI was 4.7 (score range 0-15). The mean score in the MRI was 3 (score range 0-16) according to the Eichinger score. There was a statistically significant difference between CT and MRI findings according to Helbich scoring ( $p=0.003)$. CT was superior to MRI in demonstrating mosaic attenuation. Four patients who had Phe508del homozygous mutation chronic colonised with p.aeruginosa and had higher CT and MRI scores than rest of them $(p=0.002)$.

Conclusion: Mediastinal MRI is as reliable as thoracic CT; to show pulmonary involvement in CF patients and can be preferred to reduce radiation damage. MRI can be used together with CT in the evaluation of early lung findings such as mosaic attenuation. Recently, MRI may become the gold standard with experienced staff and new imaging techniques in demonstrating lung findings in CF patients.

Key Words: Cystic Fibrosis, Computed Tomography, Magnetic Resonance İmaging, Lung İnvolvement

\section{GiRiş}

Kistik Fibrozis (KF), 2500 canlı doğumda bir görülen, çocukluk çağının en sık görülen genetik hastalıklarından biridir. Kistik Fibrozis Transmembran Regülatör (KFTR) geninde görülen mutasyonlar ile ekzokrin sekresyonların akışkanlığı azalır, uzun süreli bronşiyal obstrüksiyon, enfeksiyon ve inflamasyon, skar (fibrozis) ve bronşektazi ile karakterize kalıcı akciğer hasarı oluşur (1-3). KF'de safra kesesi, karaciğer ve pankreasta da tutulum olmakla birlikte, pulmoner komplikasyonlar morbidite ve mortalitenin \%95'inden sorumludur (1-4). Yenidoğan tarama programları ile daha erken dönemde tanı konulabilmektedir. Pulmoner yapısal değişikliklerin erken dönemde noninvaziv olarak gösterilmesi ile tedaviye daha erken başlanarak ve mevcut tedavi gözden geçirilerek komplikasyonların önüne geçilmesi ile bu hastaların morbidite ve mortalitesi azaltılabilir. Bu nedenle, İngiltere ve Avustralya KF takip yönergelerinde illk 2 yaşta asemptomatik dönemde ve ilk 6 yaşta düzelmeyen pulmoner bulguları olan hastalarda, daha önce yapılmadıysa ileri görüntüleme yöntemleri önerilmektedir $(5,6)$. Seçilen görüntüleme yöntemlerinin kolay uygulanabilir, radyasyon içermeyen, aynı zamanda pulmoner bulguları göstermede hassas olması gerekmektedir.

BT'nin KF hastalarında pulmoner bulguları ayrıntılı olarak gösterdiği, küçük çocuklarda çok erken dönemde bile hava hapsini gösterebildiği uzun zamandır bilinmektedir $(7,8)$. Uzayan yaşam süreleri ve izlemde sık BT çekilmesi ile beraber hastaların maruz kaldığı kümülatif radyasyon dozu artabilemektedir. Bilindiği üzere; Helbich skorlama sistemi uzun yllardır BT'de akciğer patolojilerinin (amfizem, bronşektazi, bronşial kalınlaşma vb.) skorlanması (maksimum puan=27) için kullanımaktadır. Son ylllarda mediastinal MRG için de modifiye edilmiştir (Tablo I.) Eichinger skorlama sistemi (maksimum puan=60) ise Helbich skorlama sistemine bazı bulgular tam uyarlanamadığı için son 10 yllda geliştirilmiştir. Eichinger skorlama sistemi
Tablo I: BT ve MRG için Helbich skorlama sistemi.

\begin{tabular}{l|c|c}
\hline & BT $^{*}$ & MRG* $^{*}$ \\
\hline Bronşektazi & $0-3$ & $0-3$ \\
\hline Bronşiyal duvarda kalınlaşma & $0-3$ & $0-3$ \\
\hline Bronşektazi yaygınlığı & $0-3$ & $0-3$ \\
\hline Mukus plağı yaygınlığı & $0-3$ & $0-3$ \\
\hline Apse ve sakkulasyon yaygınlığı & $0-3$ & $0-3$ \\
\hline Bronşiyal bölge tutulumu & $0-3$ & $0-3$ \\
\hline Bül ciddiyeti & $0-3$ & $0-3$ \\
\hline Amfizem ciddiyeti & $0-2$ & $0-2$ \\
\hline Mozaik perfüzyon ciddiyeti & $0-2$ & $0-2$ \\
\hline Kollaps/konsolidasyon ciddiyeti & $0-2$ & $0-2$ \\
\hline
\end{tabular}

*(maksimum skor $=27)$

Tablo II: MRG için Eichinger skorlama sistemi.

\begin{tabular}{l|c}
\hline & MRG* \\
\hline Bronşektazi/bronşiyal duvar kalınlaşması & 12 \\
\hline Mukus tıkacı & 12 \\
\hline Apse/sakkulasyon & 12 \\
\hline $\begin{array}{l}\text { Konsolidasyon } \\
\text { Spesifik bulgular (plevral efüzyon, plörezi, } \\
\text { pnömotoraks) }\end{array}$ & 12 \\
\hline
\end{tabular}

*(maksimum skor $=60)$

akciğer patolojlerinin mediastinal MRG'de yorumlanması için geliştirilmiştir (Tablo II). Son yıllarda mediastinal manyetik rezonans görüntüleme (MRG)'nin KF hastalarında erken dönem pulmoner yapısal değişiklikleri, pulmoner alevlenme öncesi ve sonrası tedavi yanıtını göstermede etkin olarak kullanılabileceğini bildiren az sayıda çalışma mevcuttur (9-12). Radyasyon içermeyen görüntüleme yöntemleri özellikle çocuklarda daha sık tercih edilmektedir. KF hastalarında da pulmoner tutulumu göstermekte altın standart kabul edilen BT yerine yeni çekim 
teknikleri ile MRG de tercih edilmeye başlanmıştır. MRG ile BT'de saptanan bronşektazi ve mukus tıkacı gibi pulmoner parankim bulgularının saptanabileceği bildirilmiştir (7,9-12).

\section{GEREÇ ve YÖNTEMLER}

Çalışmamızda klinik olarak stabil dönemde olan ve akciğer grafilerinde önceki akciğer grafilerine göre değişiklik olmayan hastaların BT ve MRG ile görüntülemesi yapılmış ve bundan sonraki takiplerinde akut pulmoner alevlenme gibi klinik gereklilik halinde veya 5 yılda bir tekrarlanan rutin görüntülemeleri esnasında en uygun yöntem ile görüntüleme yapılması amaçlanmıştır. Ayrıca, toraks BT ve MRG çekilen hastalardaki radyolojik bulguların birbirleri ile karșılaștırılması ve bu bulguların kronik kolonizasyon durumu ve KFTR mutasyon analizi sonucu vb. klinik bulgular ile korelasyonunu değerlendirmek amaçlanmıştır.

Çalışmada KF hastalarında akciğer tutulumu bulgularının izleminde MRG ile takip planlanır ise; gelecekte de daha sık kullanılabileceğinden MRG için spesifik skorlama sistemi olan Eichinger sisteminin de kullanılması uygun bulunmuștur. Bu nedenle; hastaların BT ve MRG'leri Helbich skorlama sistemi ile skorlanmıș; MRG'ler Helbich skorlama sistemine ek olarak Eichinger skorlama sistemi ile de skorlanmıştır. Sonuçlarda her 2 skorlama sistemini bulguları karşılaştırımıştır.

Çalışmamız için Ankara Çocuk sağlığı ve Hastalıkları Hematoloji Onkoloji Eğitim Araștırma Hastanesi, Klinik Araștırmalar Etik Kurulu'ndan 16.04.2019 tarih ve 2019-090 karar numarası ile onay alınmıştır.

Ağustos 2018 ile Şubat 2019 tarihleri arasında, hastanemiz Çocuk Göğüs Hastalıkları Kliniği'nde KF tanısı ile takip edilen, klinik olarak stabil, 18 yaș altındaki, toraks BT ve mediastinal MRG görüntülemesi yapılmış hastalar geriye dönük olarak tarandı. Hastaların yaşı, cinsiyeti, klinik ve laboratuar bulguları, kronik kolonizasyon durumu KFTR DNA sekans analizi sonuçları çocuk göğüs hastalıkları doktorları tarafından değerlendirildi.

Hastaların BT ve MRG görüntüleri, hastaların kliniği hakkında bilgisi olmayan bir pediatrik radyolog tarafından Helbich ve Eichinger skorları kullanılarak yeniden değerlendirildi (Tablo I ve II). Deneyimli pediatrik radyolog önce hastaların BT ve MRG görüntülerini Helbich skorlama sistemine göre karşılaştırmış; daha sonra MRG görüntülerini Eichinger skorlama sistemi ile değerlendirmiştir. Değerlendirme sonucunda, kontrolleri sırasında pulmoner alevlenme döneminde olan hastalar çalışma dışında bırakılmıştır.

Tüm BT görüntülemesi, 16 kesitli cihaz ile (Toshiba America Medical Systems), (100-120 kV; kesit kalınlığı $\leq 2$ mm; matriks $512 \times 512$ piksel; gantry açısı $0^{\circ}$ ) intravenöz kontrast madde kullanılmadan, hasta yaşına uygun kV (<2 yaş: $100 \mathrm{kV},>2$ yaș: 120 kV) seçilerek gerçekleştirildi. Tüm MR görüntülemeleri 1.5T cihaz ile (GE Healthcare, Milwaukee, WI) çok kanallı sarmal kullanılarak, aksiyel ve koronal T2 ağırlıkı (TR/TE:45006000/90-110 ms) sekansları kullanılarak solunum tetiklemeli olarak elde edildi. Görüntülerin kesit kalınlığı 3-4 mm, ortalama çekim süresi 7 dakikadı. MR görüntülemeler, küçük çocuklarda yüzeyel sedasyonlu (klorohidrat) veya sedasyon kullanılmadan kendi uykusu altında gerçekleştirildi.

\section{İstatistiksel Analiz}

Kategorik değişkenler, sayı ve yüzde ile sayısal değişkenler ortalama \pm standart sapma (SD) șeklinde verildi. Tüm analizler SPSS ile (versiyon 22.0, SPSS Inc., Chicago, IL) yapıldı ve $\mathrm{p}<0.05$ istatistiksel olarak anlamlı kabul edildi.

\section{BULGULAR}

Çalışmaya KF tanısı ile takip edilmekte olan pulmoner alevlenme şikayeti olmayan 14 hasta dahil edildi. Hastaların 10'u (\%71.4) erkek, 4'ü (\%28.6) kızdı; yaş ortancası 3.9 yıl (1 en küçük-18 en büyük)'dü (Tablo III). Çalışmaya dahil edilen klinik olarak stabil $14 \mathrm{KF}$ hastasına aynı gün veya yakın tarihlerde BT ve MRG çekilmiști (BT=14, MRG=14). Akut pulmoner alevlenme döneminde olan 3 hasta çalışma dışı bırakılmıştı. Noninvaziv mekanik ventilasyon (NIMV) ile izlenen bir (\%7.1) hasta dişında kronik solunum yetmezliği nedeniyle tedavi alan hastamız yoktu. Bir hasta dişında tüm hastalarımız (\%92.8) inhale dornaz alfa tedavisini düzenli kullanmaktaydı. Beş (\%35.7) hasta P. aeruginosa ile kronik kolonizeydi. S.aureus ile kronik kolonize

\begin{tabular}{|c|c|c|}
\hline & $n=14$ & $\%$ \\
\hline Yaş ortancası & \multicolumn{2}{|c|}{3.9 (1-18 yaş) } \\
\hline $\mathrm{E} / \mathrm{K}$ & $10 / 4$ & $71.4 / 28.6$ \\
\hline Malnütrisyon & 2 & 14.2 \\
\hline Yenidoğan tarama programı ile tanı & 2 & 14.2 \\
\hline Dornaz Alfa kullanımı & 13 & 92.8 \\
\hline$P$. aeruginosa ile kronik kolonizasyon & 5 & 35.7 \\
\hline Normal spirometria & $3 / 4$ & 75 \\
\hline NIMV & 1 & 7.1 \\
\hline KFTR DNA Sekans Analizi & 14 & 100 \\
\hline F508del homozigot & 4 & 28.5 \\
\hline Q220X / 2789+5G->A & 1 & 7.1 \\
\hline R334Q / p.Phel152 & 1 & 7.1 \\
\hline R1070Q Homozigot & 1 & 7.1 \\
\hline 457TAT->G Homozigot & 1 & 7.1 \\
\hline S466X Homozigot & 1 & 7.1 \\
\hline G314E Homozigot & 1 & 7.1 \\
\hline 2184delA / 3878 delG & 1 & 7.1 \\
\hline G542 / D58N & 1 & 7.1 \\
\hline G85E Homozigot & 1 & 7.1 \\
\hline c. $2657+5 G>A$ Homozigot & 1 & 7.1 \\
\hline
\end{tabular}

E: erkek; K: kadın; NIMV: non invaziv mekanik ventilasyon; KFTR: kistik fibrozis transmembran regülatör; min: minimum; max: maksimum. a:(FEV1>\%80, FVC>\%80, FEF 25-75>\%70, FEV1/FVC>80) 
Tablo IV: KF hastalarının BT ve MRG bulgularının karşılaştırılması.

\begin{tabular}{|c|c|c|c|c|c|}
\hline \multirow{2}{*}{ Parankimal Bulgular } & \multicolumn{2}{|c|}{ BT } & \multicolumn{2}{|c|}{ MRG } & \multirow{2}{*}{$\mathbf{p}$} \\
\hline & $n=14$ & $\%$ & $n=14$ & $\%$ & \\
\hline Bronşektazi/peribronşial kalınlașma & 10 & 71.4 & 10 & 71.4 & $>0.05$ \\
\hline Mozaik atenüasyon & 7 & 50 & 1 & 7.1 & ${ }^{\star} 0.003$ \\
\hline Mukus tıkacı & 4 & 28.5 & 4 & 28.5 & $>0.05$ \\
\hline $\begin{array}{l}\text { Skorlama } \\
\text { Helbich Skoru, ortalama skor } \pm \text { standart sapma } \\
\text { Eichinger Skoru, ortalama skor } \pm \text { standart sapma }\end{array}$ & \multicolumn{2}{|c|}{$6.6 \pm 2.2$ (skor aralığı, 1-17) } & \multicolumn{2}{|c|}{$\begin{array}{c}4.7 \pm 2.3 \text { (skor aralığı, } 0-15) \\
3 \pm 2.2 \text { (skor aralığı, } 0-16 \text { ) }\end{array}$} & $>0.05$ \\
\hline
\end{tabular}

olan hastamız yoktu. KFTR DNA sekans analizi sonuçları ile 4 (\%28.5) hastada Phe508del homozigot mutasyonu olduğu gösterildi (Tablo III). Spirometre de koopere olabilen 4 (\%28.5) hastadan P. aeruginosa ile kronik kolonize, Phe508del homozigot mutasyonu olan NIMV ile izlenen bir hastamızın ağır restriksiyonu mevcuttu. Diğer üç (\%75) hastanın ise spirometre değerleri normaldi (FEV1>\%80, FVC>\%80, FEF 25-75>\%70, FEV1/FVC>80) (Tablo III).

BT'de hastaların \%71.4'ünde (10/14) bronşektazi ve peribronșial kalınlaşma, \%57.1'inde (8/14) tomurcuklanmış ağaç manzarası, \%50'sinde (7/14) mozaik atenüasyon, \%28.5'inde (4/14) mukus tıkacı, \%28.5'inde (4/14) lineer-subsegmental atelektazi saptandı (Tablo III).

Helbich skorlama sistemine göre BT'de ortalama skor $6.6 \pm$ 2.2 (skor aralığı, 1-17), MRG'de 4.7 \pm 2.3 (skor aralığı, 0-15)'di. Eichinger skorlamasına göre MRG için ortalama skor $3 \pm 2.2$ (skor aralığı 0-16)'di. BT ve MRG bulguları karșılaștıııldığında, Helbich skorlama sisteminde değerlendirilen kriterler arasında sadece mozaik atenüasyon paterninde istatistiksel olarak anlamlı fark saptandı $(p=0.003)$. Diğer kriterlerde anlamlı fark görülmedi ( $p>0.05$ ) (Tablo IV) (Şekil 1).

Hastaların klinik ve demografik bulguları karșılaștııılıı̆ında F508 delesyonu homozigot mutasyonu olup $P$. aeruginosa ile kronik kolonize olan dört (\%28.5) hastanın yaș ortancası 8.9 (6.5 en küçük-20 en büyük)'tü. Bu hastaların BT ve MRG skorları, yaş ortancası 3.9 (1-20 yaş) olan diğer hastalara göre anlamlı olarak daha yüksekti $(p=0.002)$.

\section{TARTIŞMA}

$\mathrm{Bu}$ retrospektif kesitsel çalıșmada klinik olarak stabil iken çekilen BT ve MRG' de mozaik atenüasyon dıșındaki akciğer bulgularında istatistiksel olarak anlamlı fark olmadığı saptandı. KF'de erken dönemde periferal hava yolu inflamasyonu, enfeksiyonlar ve bozulmuș mukosiliyer klirens ile bașlayan akciğer hasarı, geri dönüşümsüz yaygın bronşektaziler ve son dönemde kronik solunum yetmezliği nedeni olabilir $(13,14)$. Akut pulmoner alevlenmede solunum fonksiyon testleri etkilenmeden önce BT'de de klinik ile korele değişiklikler görüldüğü, uzun dönem izlemde de pulmoner alevlenme sayısı arttıkça BT bulgularının da belirginleştiği gösterilmiştir $(8,15)$.

Merkezimizde de KF hastalarımı için rutin BT çekimi yapılmamakta, gereklilik halinde kontrast madde kullanılarak BT çekilmektedir. Şikayet olması halinde veya yillik kontroller sırasinda rutin akciğer grafisi çekilmektedir. Çalısmamızda klinik olarak stabil dönemde olan ve akciğer grafilerinde önceki akciğer grafilerine göre değişiklik olmayan hastaların BT ve MRG ile görüntülemesi yapılmıştır. Akciğer grafisi ucuz, hızlı ve yaygın kullanılan bir yöntemdir; bu nedenle yilda bir kontrol amaçlı ve gereklilik halinde daha erken çekilmesi önerilmektedir (13). Grafiler atelektazi, konsolidasyon, plevral efüzyon gibi anormalliklerin tanısında yararıdır; ancak bronşektazi tanısında hassasiyeti düşüktür (16). KF hastalarında erken dönemde önce geri dönüşümlü küçük hava yolu hastalığı, zamanla bronşektazi gelișimi ile kalıcı akciğer hasarına yol açarak yaşam kalitesini düşürmekte; morbidite ve mortaliteyi arttırmaktadır (17-20). Küçük hava yolu hastalı̆ı̆ın erken dönemde tespiti mümkün olduğunda; etkin fizyoterapi ve postural drenaj, enfeksiyonlardan korunma ve gerektiğinde dornaz alfa tedavisi ile bulgularda bir miktar düzelme sağlanabilir (21). BT ile tüm akciğer parankimi ayrıntılı değerlendirilip, bronșektazi tanısı konulabilmektedir (22-24). Küçük hava yolu hastalı̆ı̆ın gösterilmesinde en çok bilinen ve sık kullanılan yöntem BT'dir (25). BT çekim sıklı̆ı ve endikasyonları ile ilgili klinikte bazı görüș ayrlıkları görülmektedir. Bazı merkezler, ilk bir yıldan başlayarak en az 2 yilda bir kontrol BT çekilmesini önermekte iken; bazı merkezler ise BT'nin rutin kullanımını önermemektedir $(17,24)$. Ingiltere'de 27 merkezli 3.basamak KF takip ve tedavi merkezinde yapılan bir anket çalsşmasında klinisyenlerin \%93'ü BT'yi hastalık progresyonunda (en sık nontüberküloz mikobakteriler ve allerjik bronkopulmoner aspergillozis) kullanmış ve \%70'i de BT sonuçlarının tedaviyi yönlendirdiğini belirtmiștir, ancak sadece \%17'si yillık rutin BT önermiştir (25). Klinisyenlerin \%14'ü ekspiratuar fazda, \%5'i de intravenöz kontrast ile BT kullanmıştır (25). BT ile hastalığın çok erken döneminde bile hafif pulmoner değișiklikler saptanabilir; bu nedenle değișken endikasyonlarda sıklıkta kullanılmaktadır.

Çalıșmamızda da BT ve MRG bulguları benzerlik göstermiștir. Yaşı küçük olan çocuk hastalarda kooperasyonun az olması 


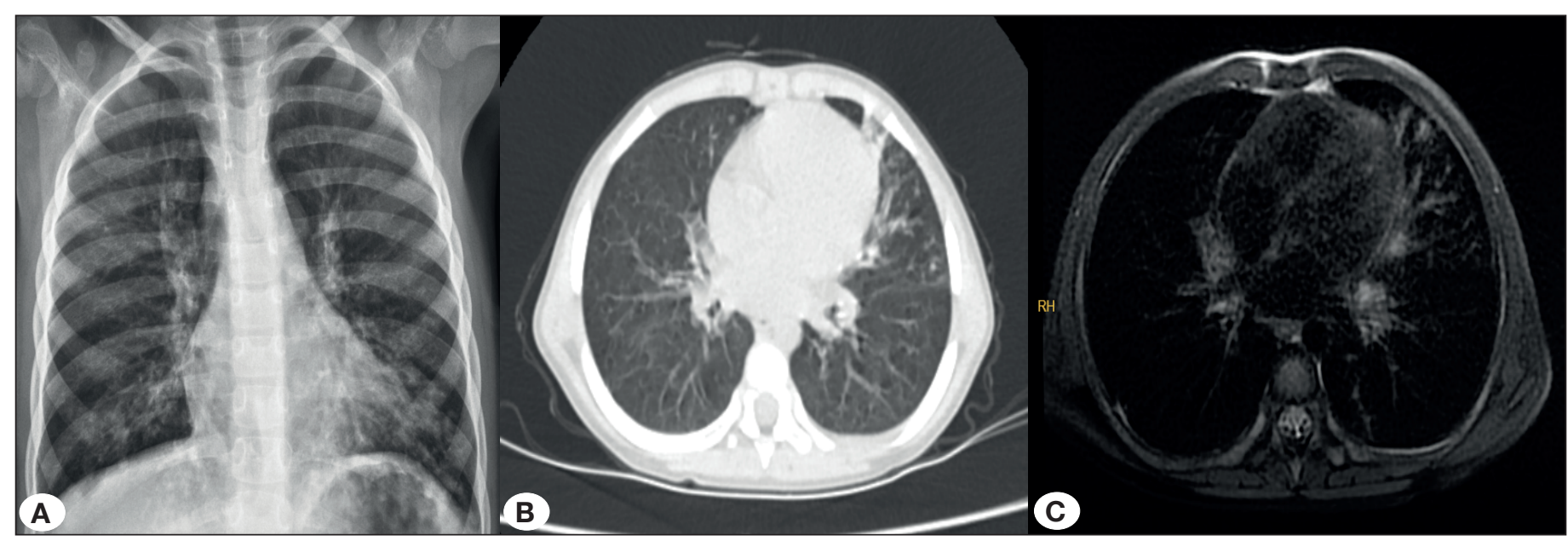

Şekil 1: KF hastasında akciğer grafisi, BT ve MRG Görüntüleme Bulguları KF nedeniyle takipte, Phe508del mutasyonu olan yaygın sol akciğerde daha bronşektazileri olan 5 yaşında bir hastanın; (A) Akciğer Grafisi: Bilateral sol akciğerde daha belirgin parakardiyak peribronşiyal kalınlaşma ve atelektazi mevcut; (B) BT: sol lingüler bronşektazi ve atelektazi, bilateral peribronşial kalınlaşma ve mozaik atenüasyon mevcut; (C) MRG: BT ile benzer bulgular mevcut ancak mozaik atenüasyon gösterilemedi.

nedeniyle çalıșmamıza dahil edilen hastalarda ekspiratuar fazda BT çekimi yapılmamıştır. Mozaik atenüasyon, ekspiratuar fazda elde edilen BT'lerde daha belirgin olarak seçilebilse de, inspirasyon fazında elde edilen BT'lerde de görülebilmektedir. BT'nin iyonizan radyasyon içeren bir görüntüleme yöntemi olması nedeniyle son yıllarda rutin kullanımı tartışılmaya başlanmıştır $(26,27)$. Radyasyon maruziyetinin olmaması nedeniyle KF hastaları için MRG'nin akciğer hasarını gösterme başarısı ile çalışmalar artmıştır. MRG'deki tetkik sürelerinin hızlı görüntülemeye imkan sağlayan sekanslar (Ultra-short TR/TE 2D Steady State Free Precession ile Sequence) ile kısalması, görüntülerin solunum ile senkron elde edilebilmesi ile akciğer parankimini değerlendirmek mümkün olabilmektedir (28). Ayrıca, KF olan çocuk hastalarda da erişkinlerde olduğu gibi; inhale $3 \mathrm{He}$ ve 129Xse ile MRG çekiminin tolere edilebilir olduğu ve ilk 1 yaşta bile küçük hava yollarındaki hafif değişikliklerin ve bölgesel ventilasyon bozukluklarının görüntülendiği bildirilmiştir $(29,30)$. MR görüntülemede çocuk hastalarda karşılaşılan en büyük problem hasta ile olan kooperasyondur. Özellikle küçük yaştaki çocuklarda yüzeyel veya genel sedasyon intiyacı olabilmektedir. Literatürde KF hastalarında MR görüntüleme kullanımı ile ilgili birkaç çalıșma bulunmaktadır. 2014'te Sileo ve ark. (33), yaș ortalaması 12.5 yll olan $17 \mathrm{KF}$ hastasının rutin BT çekimi esnasında MRG'lerini çekmiș, Eisenger ve Helbich skorları ile BT ve MRG bulgularını karşılaştırmıştır. Her iki skorlama sisteminin birbiri ile korelasyon gösterdiği; mukus tıkacı, bronşektazi, peribronşial kalınlaşma skorlarının BT ve MRG de benzer olduğu ve en önemlisi ekspiratuar fazda çekilen MRG'de T2 ağırlıklı görüntülerde mozaik atenüasyonun gösterilebildiği bildirilmiştir (31). Almanya'da 0-6 yaş arası $50 \mathrm{KF}$ hastasına stabil dönemde MRG çekilmiş; ilk 1 yıl dahil olmak üzere, bronşial duvar kalınlaşması, mukus tıkacı, bronşektazi ve perfüzyon bozuklukları gösterilebilmiştir (9). Bu çalışmada ayrıca akut pulmoner alevlenmede MRG skorlarının yükseldiği ve tedaviden 1 ay sonra anlamlı olarak düștüğü de gösterilmiștir (9).

Çalışmamızda BT'de mozaik atenüasyon saptanan 7 hastadan sadece 1'inde MRG'de mozaik atenüasyon saptanabilmiştir. Çalışmamızda elde edilen MR görüntülerde daha önceki çalışmalardan farklı olarak mozaik atenüasyonun BT'den daha az saptanabildiği görülmüştür. MRG'de normalde havaya ait sinyal kaydı bulunmamakta olup akciğer parankiminde havalanma artışı gösteren parankim alanında da sinyal farklıı̆ı saptanamamaktadır. Akciğerlerde hava hapsi alanları gösteren parankim ile normal parankim arasındaki sinyal farkının saptanabilirliğinin, ekspiratuar ve inspiratuar fazlarda alınan görüntülerin karşılaștırılması ile mümkün olabileceği bildirilmiştir (32).

Çalışmamızda da $P$. aeruginosa ile kronik kolonize olan ve Phe508del homozigot mutasyonu olan hastalarımızın BT ve MRG skorları birbiriyle korele olarak daha yüksekti. Bu durum, KF hastalarında genetik faktörlerin etkisi ve sık pulmoner alevlenmeler ile akciğer tutulumunun yaşla artması ile ilişkilendirildi.

Bronşektazi (BE) ile ilgili yapısal değişikliklerin yenidoğan ve erken infantil dönemde BT'de hafif hava hapsi bulguları ile başladığı ve inflamasyon ile ilerleme gösterdiği saptanmıştır (12,33-35). BT bulguları ile yapılan klinik korelasyonlarda bronşektazi gelişiminde, $P$. aeruginosa enfeksiyonu ve kolonizasyonunun inflamasyonu ve akciğer hasarını arttıran en önemli faktörlerden biri olduğu gösterilmiştir $(18,20,35)$. P. aeruginosa bronşektazi gelişimi ile yaşam kalitesini düşürmekte ve son dönem akciğer hastalığında mortalitenin en önemli komponentlerinden biri olmaktadır $(14,20)$. Bu nedenle; akciğer hasarının erken dönemde gösterilmesi ve enfeksiyonların önlenmesi ile bronşektazi ilişkili akciğer hasarının yavaşlatıması amaçlanmaktadır. 
Çalışmamızda solunum fonksiyon testlerinden spirometreye kooepere olan hasta sayımız radyolojik bulgular ile klinik korelasyon yapmak için yetersizdi. Her ikisi de iyonizan radyasyon içermeyen, noninvaziv ve küçük çocuklarda da uygulanabilen solunum fonksiyon testlerinden lung clearance index $(\mathrm{LCl})$ ve MRG'nin koordine kullanımı son dekatta giderek artmaktadır (36). Bilindiği üzere spirometre FEV1 yüzdeleri düșmeden önce Nitrojen Multiple Breath Washout (MBW) tekniği ile LCl de ventilasyon heterojenitesi saptanabilmektedir. Illk olarak, spirometride FEV1 yüzdeleri normal olan KF hastalarında da hafif değişikliklerin 129Xse MRG ile erken dönemde saptandığı bildirilmiştir (36). LCl'in kullanımının sıklaşması ile; MRG'de erken parankimal bulguların LCl ile korelasyonunu gösteren çalışmalar artış göstermektedir. Stahl ve ark. (37) 2017'de yaptığı bir çalışmada, KF hastalarında stabil dönemde LCl yüksekliği ile görülen ventilasyon heterojenitesinin (VH), MRG' de bölgesel mukus plağı ve hipoperfüzyon ile yükselen ventilasyon defekti yüzdesi (VDY) ile lokalize edilebildiğini bildirmiştir. Ayrıca bu hastalarda akut pulmoner alevlenme esnasında $L C l$ ve MRG global skorlarının birbirleri ile korele olarak yükseldiği; uygun tedavi sonrasında düştüğü de gösterilmiştir (37). 2020'de Couch MJ ve ark.(38) stabil dönemde ve akut pulmoner alevlenme döneminde solunum fonksiyon testlerinden FEV1, LCl ile görüntüleme yöntemlerinden PREFUL ve 129Xse MRG bulgularını karşılaştııımıştır. KF hastalarında stabil dönemde FEV1 yüzdeleri normal, LCI VH'ni gösterecek şekilde yüksek iken; hem 129Xse MRG hem de PREFUL MRG'de VDY benzer oranda gösterilebilmiştir $(39,40)$. Akut pulmoner alevlenmede ise; FEV1 düşük ve LCl yüksek iken 129Xse MRG ve PREFUL MRG'de VDY'nin arttığl; uygun tedavi ile FEV1 ve LCl düzelirken gene her iki MRG'de de düzelme gösterilmiştir (41). Bu yöntemlerden normal tidal ventilasyon esnasında daha az aplikasyon ile çekilebilen PREFUL MRG'nini kullanımının teknik olarak daha kolay olduğu bildirilmiştir (41).

Çalışmamııın kısıt|lıklarından birisi solunum fonksiyon testlerinden spirometre dışında pletismografi, LCl yapılamaması ve bu nedenle 6 yaş altı hastalarımı için görüntüleme yöntemleri ile korelasyon yapilamamasıdir.

Bir diğer kısıtlllık ise teknik şartlar nedeniyle tüm hastalarda ekspiratuar fazda MRG çekilememesidir, ancak mevcut MRG tekniği ile mozaik atenüasyon dışındaki parankimal bulgular BT ile karşlaştırlabilmiştir

Daha çok hastanın dahil olduğu; KF hastalarının 1 yaştan itibaren izlendiği, prospektif, randomize kontrollü çalsşmalara ihtiyaç vardır.

\section{SONUÇ}

KF hastalarında pulmoner etkilenmeyi erken dönemde göstermek için MRG güvenilir; radyasyon içermediği için de tercih edilebilir bir yöntemdir. Yakın zamanda KF hastalarındaki akciğer bulgularını göstermede yapılacak daha büyük çaplı çalışmalar ile MRG altın standart haline gelebilir.

\section{KAYNAKLAR}

1. Ratjen F, Bell SC, Rowe SM, Goss CH, Quittner AL, Bush A. Cystic fibrosis. Nat Rev Dis Primers 201;1:15010.

2. Paranjape SM, Mogayzel PJ Jr. Cystic fibrosis. Pediatr Rev 2014;35:194-205.

3. Horsley A. Book review: Hodson and Geddes' Cystic Fibrosis. Breathe 2016;12:91-2.

4. Cystic Fibrosis Lung Disease: An OvervieW Nelson L Turcios Respiratory Care Feb 2020;65:233-51.

5. Kołodziej M, de Veer MJ, Cholewa M, Egan GF, Thompson BR. Lung function imaging methods in Cystic Fibrosis pulmonary disease. Respir Res 2017;18:96.

6. Villanueva G, Marceniuk G, Murphy MS, Walshaw M, Cosulich R; Guideline Committee. Diagnosis and management of cystic fibrosis: summary of NICE guidance. BMJ 2017;359:j4574.

7. Newbegin K, Pilkington K, Shanthikumar S, Ranganathan S. Clinical utility of surveillance computed tomography scans in infants with cystic fibrosis. Pediatr Pulmonol 2018;53:1387-90.

8. Sanders DB, Li Z, Brody AS. Chest computed tomography predicts the frequency of pulmonary exacerbations in children with cystic fibrosis. Ann Am Thorac Soc 2015;12:64-9.

9. Wielpütz MO, Puderbach $M$, Kopp-Schneider A, Stahl M, Fritzsching E, Sommerburg $O$, ve ark. Magnetic resonance imaging detects changes in structure and perfusion, and response to therapy in early cystic fibrosis lung disease. Am J Respir Crit Care Med 2014;189:956-65.

10. Theilmann RJ, Darquenne C, Elliott AR, Bailey BA, Conrad DJ. Characterizing Lung Disease in Cystic Fibrosis with Magnetic Resonance Imaging and Airway Physiology. PLoS One 2016;11:e0157177.

11. Anjorin A, Schmidt H, Posselt HG, Smaczny C, Ackermann H, Deimling $\mathrm{M}$, ve ark. Comparative evaluation of chest radiography, low-field MRI, the Shwachman-Kulczycki score and pulmonary function tests in patients with cystic fibrosis. Eur Radiol 2008;18:1153-61.

12. Thia LP, Calder A, Stocks J, Bush A, Owens CM, Wallis C, ve ark. London Cystic Fibrosis Collaboration. Is chest CT useful in newborn screened infants with cystic fibrosis at 1 year of age? Thorax 2014;69:320-7.

13. Loeve $M$, van Hal PT, Robinson $P$, de Jong PA, Lequin $M H$, Hop WC, ve ark. The spectrum of structural abnormalities on CT scans from patients with CF with severe advanced lung disease. Thorax 2009;64:876-82.

14. Loeve M, Hop WC, de Bruijne M, van Hal PT, Robinson P, Aitken ML, ve ark. Computed Tomography Cystic Fibrosis Survival Study Group. Chest computed tomography scores are predictive of survival in patients with cystic fibrosis awaiting lung transplantation. Am J Respir Crit Care Med 2012;185:1096-103.

15. Brody AS, Sucharew H, Campbell JD, Millard SP, Molina PL, Klein JS, Quan J. Computed tomography correlates with pulmonary exacerbations in children with cystic fibrosis. Am J Respir Crit Care Med 2005;172:1128-32.

16. Jacobsen LE, Houston CS, Habbick BF, Genereux GP, Howie JL. Cystic fibrosis: a comparison of computed tomography and plain chest radiographs. Can Assoc Radiol J 1986;37:17-21.

17. Stick SM, Brennan S, Murray C, Douglas T, von Ungern-Sternberg BS, Garratt LW, ve ark. Australian Respiratory Early Surveillance Team for Cystic Fibrosis (AREST CF). Bronchiectasis in infants and 
preschool children diagnosed with cystic fibrosis after newborn screening. J Pediatr $2009 ; 155: 623-8 . e 1$.

18. Mott LS, Park J, Murray CP, Gangell CL, Klerk NH, Robinson PJ, ve ark. Progression of early structural lung disease in young children with cystic fibrosis assessed using CT. Thorax 2012;67:509-16.

19. Wainwright CE, Vidmar S, Armstrong DS, Byrnes CA, Carlin $\mathrm{JB}$, Cheney J, ve ark. ACFBAL Study Investigators. Effect of bronchoalveolar lavage-directed therapy on Pseudomonas aeruginosa infection and structural lung injury in children with cystic fibrosis: a randomized trial. JAMA 2011;306:163-71.

20. Tepper LA, Utens EM, Caudri D, Bos AC, Gonzalez-Graniel K, Duivenvoorden $\mathrm{HJ}$, ve ark. Impact of bronchiectasis and trapped air on quality of life and exacerbations in cystic fibrosis. Eur Respir J 2013;42:371-9.

21. Yang C, Montgomery M. Dornase alfa for cystic fibrosis. Cochrane Database Syst Rev 2018;9:CD001127.

22. Kerem E, Conway S, Elborn S, Heijerman H; Consensus Committee. Standards of care for patients with cystic fibrosis: a European consensus. J Cyst Fibros 2005;4:7-26.

23. Hansell DM, Strickland B. High-resolution computed tomography in pulmonary cystic fibrosis. Br J Radiol 1989;62:1-5.

24. Hansell DM. Bronchiectasis. Radiol Clin North Am 1998;36:10728.

25. Arakawa $\mathrm{H}$, Webb WR. Air trapping on expiratory high-resolution CT scans in the absence of inspiratory scan abnormalities: correlation with pulmonary function tests and differential diagnosis. AJR Am J Roentgenol 1998;170:1349-53.

26. Gilchrist FJ, Buka R, Jones M, Ho SA, Lenney W, Carroll WD. Clinical indications and scanning protocols for chest CT in children with cystic fibrosis: a survey of UK tertiary centres. BMJ Paediatr Open 2018;2:e000367.

27. de González AB, Kim KP, Samet JM. Radiation-induced cancer risk from annual computed tomography for patients with cystic fibrosis. Am J Respir Crit Care Med 2007;176:970-3.

28. Ferris H, Twomey M, Moloney F, O'Neill SB, Murphy K, O'Connor OJ, ve ark. Computed tomography dose optimisation in cystic fibrosis: A review. World J Radiol 2016;8:331-41.

29. Roach DJ, Crémillieux Y, Fleck RJ, Brody AS, Serai SD, Szczesniak $\mathrm{RD}$, ve ark. Ultrashort Echo-Time Magnetic Resonance Imaging Is a Sensitive Method for the Evaluation of Early Cystic Fibrosis Lung Disease. Ann Am Thorac Soc 2016;13:1923-31.

30. Walkup LL, Thomen RP, Akinyi TG, Watters E, Ruppert K, Clancy JP, ve ark. Feasibility, tolerability and safety of pediatric hyperpolarized
129Xe magnetic resonance imaging in healthy volunteers and children with cystic fibrosis. Pediatr Radiol 2016;46:1651-62.

31. Thomen RP, Walkup LL, Roach DJ, Cleveland ZI, Clancy JP, Woods JC. Hyperpolarized 129Xe for investigation of mild cystic fibrosis lung disease in pediatric patients. J Cyst Fibros 2017;16:275-82.

32. Sileo C, Corvol H, Boelle PY, Blondiaux E, Clement A, Ducou Le Pointe H. HRCT and MRI of the lung in children with cystic fibrosis: comparison of different scoring systems. J Cyst Fibros. 2014;13:198-204.

33. Davis SD, Fordham LA, Brody AS, Noah TL, Retsch-Bogart GZ, Qaqish BF, ve ark. Computed tomography reflects lower airway inflammation and tracks changes in early cystic fibrosis. Am J Respir Crit Care Med 2007;175:943-50.

34. Amin R, Charron M, Grinblat L, Shammas A, Grasemann H, Graniel $\mathrm{K}$, ve ark. Cystic fibrosis: detecting changes in airway inflammation with FDG PET/CT. Radiology 2012;264:868-75.

35. Sly PD, Gangell CL, Chen L, Ware RS, Ranganathan S, Mott LS, ve ark. AREST CF Investigators. Risk factors for bronchiectasis in children with cystic fibrosis. N Engl J Med 2013;368:1963-70.

36. Failo R, Wielopolski PA, Tiddens HA, Hop WC, Mucelli RP, Lequin $\mathrm{MH}$. Lung morphology assessment using MRI: a robust ultra-short TR/TE 2D steady state free precession sequence used in cystic fibrosis patients. Magn Reson Med 2009;61:299-306.

37. Stahl M, Wielpütz MO, Graeber SY, Joachim C, Sommerburg O, Kauczor HU, ve ark. Comparison of Lung Clearance Index and Magnetic Resonance Imaging for Assessment of Lung Disease in Children with Cystic Fibrosis. Am J Respir Crit Care Med 2017;195:349-59.

38. Couch MJ, Munidasa S, Rayment JH, Voskrebenzev A, Seethamraju RT, Vogel-Claussen J, ve ark. Comparison of Functional FreeBreathing Pulmonary $1 \mathrm{H}$ and Hyperpolarized 129Xe Magnetic Resonance Imaging in Pediatric Cystic Fibrosis. Acad Radiol 2020:S1076-6332(20)30284-1.

39. Couch MJ, Thomen R, Kanhere N, Hu R, Ratjen F, Woods J, ve ark. A two-center analysis of hyperpolarized 129Xe lung MRI in stable pediatric cystic fibrosis: Potential as a biomarker for multisite trials. J Cyst Fibros 2019;18:728-33.

40. Ranganathan SC, Hall GL, Sly PD, Stick SM, Douglas TA; Australian Respiratory Early Surveillance Team for Cystic Fibrosis (AREST-CF). Early Lung Disease in Infants and Preschool Children with Cystic Fibrosis. What Have We Learned and What Should We Do about It? Am J Respir Crit Care Med 2017;195:1567-75.

41. Long FR, Williams RS, Castile RG. Structural airway abnormalities in infants and young children with cystic fibrosis. J Pediatr $2004 ; 144: 154-61$. 